\title{
An Efficient Three-step Synthesis of $\beta$-Phenethylcinnamamides Toward New Biological Active Compounds
}

\author{
Carlos E. Puerto Galvis, Vladimir V. Kouznetsov*
}

Laboratorio de Química Orgánica y Biomolecular, Universidad Industrial de Santander, Cra 27 Calle 9, A.A. 687, Bucaramanga, Colombia.

*kouznet@uis.edu.co.

Keywords: $\beta$-Phenylethylamines, $\beta$-Phenethylcinnamamides, Boric Acid.

\section{INTRODUCTION}

Most of the family members of $\beta$-phenethylamides constitute an important part of the natural and synthetic products discover so far. ${ }^{1}$ The biological importance of these small molecules (SM) is based on their selectivity to induced apoptosis in different malignant cell lines, including melanoma and leukemia. ${ }^{2}$ Due to the value of these amides in cancer research and the difficult to extract their analogues from natural sources, i.e. Isodon excisus. $^{3}$ The responsibility to develop a novel synthetic protocols that allow the preparation of new libraries of $\beta$-phenethylcinnamamides lies on organic chemistry (Scheme 1).
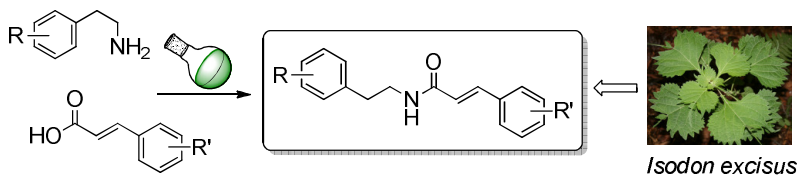

Scheme 1. Synthetic and natural sources of phenethylcinnamamides

According to the aspects described above and our current interests in $\mathrm{N}$-phenethylcinnamamides, we designed a strategy for the preparation of these compounds under the parameters of green chemistry and improving some synthetic aspects.

\section{RESULTS AND DISCUSSION}

Our synthetic plan required a series of $\beta$ phenylethylamines $\mathbf{3 a}$ - $\mathbf{d}$ that were prepared through the reduction of the corresponding $\beta$-nitrostyrenes 2a-d. ${ }^{4}$ These nitroalkanes were prepared in excellent yield from the respective aldehydes 1a-d using ethanolamine supported on $\mathrm{SiO}_{2}\left(\mathrm{ETAM} / \mathrm{SiO}_{2}\right)$ as a catalyst ${ }^{5}$ (Scheme 2 ).

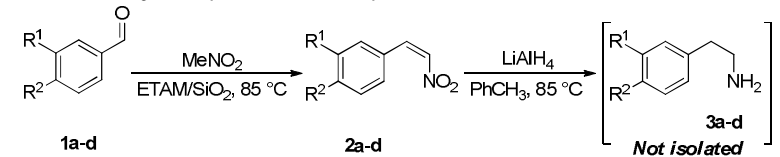

Scheme 2. Preparation of $\beta$-phenylethylamines 3a-d.

In the final stage, each $\beta$-phenylethylamine was mixed with boric acid $(10 \% \mathrm{~mol})$ and trans-cinnamic acid $4 a-b$ in toluene at $110{ }^{\circ} \mathrm{C}$ leading the desired amides $\mathbf{5 a}-\mathbf{h}$ in good to excellent yields ${ }^{6}$ (Scheme 3 ).

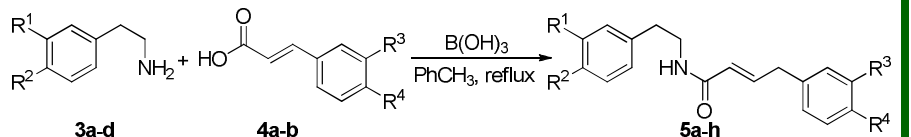

Scheme 3. Synthesis of new $\beta$-phenethylcinnamamides.

All products $\mathbf{5 a - h}$ (Table 1) were obtained as stable solids that were characterized by IR, mass spectrometry and NMR $\left({ }^{1} \mathrm{H},{ }^{13} \mathrm{C}\right)$.

Table 1. New $\beta$-phenethylcinnamamides obtained.

\begin{tabular}{cccccc}
\hline Comp. & $\mathbf{R}^{\mathbf{1}}$ & $\mathbf{R}^{2}$ & $\mathbf{R}^{3}$ & $\mathbf{R}^{4}$ & Yield, \%* \\
\hline $\mathbf{5 a}$ & $\mathrm{H}$ & $\mathrm{H}$ & $\mathrm{H}$ & $\mathrm{H}$ & 98 \\
$\mathbf{5 b}$ & $\mathrm{H}$ & $\mathrm{H}$ & $-\mathrm{OCH}_{2} \mathrm{O}-$ & 93 \\
$\mathbf{5 c}$ & $\mathrm{H}$ & $\mathrm{F}$ & $\mathrm{H}$ & $\mathrm{H}$ & 99 \\
$\mathbf{5 d}$ & $\mathrm{H}$ & $\mathrm{F}$ & $-\mathrm{OCH}_{2} \mathrm{O}-$ & 87 \\
$\mathbf{5 e}$ & $\mathrm{H}$ & $\mathrm{OMe}$ & $\mathrm{H}$ & $\mathrm{H}$ & 98 \\
$\mathbf{5 f}$ & $\mathrm{H}$ & $\mathrm{OMe}$ & $-\mathrm{OCH}_{2} \mathrm{O}-$ & 84 \\
$\mathbf{5 g}$ & $\mathrm{OMe}$ & $\mathrm{OMe}$ & $\mathrm{H}$ & $\mathrm{H}$ & 97 \\
$\mathbf{5 h}$ & $\mathrm{OMe}$ & $\mathrm{OMe}$ & $-\mathrm{OCH}_{2} \mathrm{O}-$ & 81 \\
*Isolated yield. & & & &
\end{tabular}

Reducing the $\beta$-nitrostyrenes in toluene lead the complete conversion (TLC) into the desired amine and allow it's used in the final step without further purification, facilitating their handling and integrity.

\section{CONCLUSION}

We have developed an efficient and easy protocol for the synthesis of $\beta$-phenethylcinnamamides, from available commercial reagentes, under green and mild conditions. The obtained compounds could serve for a SM screening in different biological systems.

\section{ACKNOWLEDGEMENTS}

We thank to Universidad Industrial de Santander for their constant financial support.

\section{REFERENCES}

${ }^{1}$ Larghi, E. L.; Kaufman, T. S. J. Braz.Chem. Soc. 2006, 17, 599-602.
${ }^{2}$ Nesterenko, V.; Putt, K. S.; Hergenrother, P. J. J. Am. Chem. Soc. 2003 125, 14672-14673.

Sienkiewicz, P.; Ciolino, H, P.; Leslie, B, J.; Hergenrother, P, J.; Singletary, K.; Chao Yeh, G. Carcinogenesis 2007, 28, 1052-1057.

${ }^{4}$ Sikazwe, D.;Bondarev, M. L.; Dukat, M.; Rangisetty, J. B.; Roth, B. L.; Glennon, R. A. Tetrahedron, 2006, 62, 594-604.

${ }^{5}$ Mora, M.; Jiménez-Sanchidrián, C.; Urbano, F, J.; Ruiz, J. R. Catal. Lett. 2010, 134, 131-137.

Hernandez Barajas J. G.; Vargas Mendez L. Y; Kouznetsov V. V.; Stashenko E. E. Synthesis 2008, 3, 377-382. 